\title{
Hectopsylla pulex (Haller, 1880) (Siphonaptera: Tungidae) infestation on Eptesicus furinalis (Chiroptera: Vespertilionidae) in the Central Andes of Colombia
}

\author{
Juan C. Cepeda-Duque ${ }^{1,7}$; Luis F. Ruiz-Correa ${ }^{2,8}$; Alexandra Cardona-Giraldo ${ }^{3,9}$; Paula A. Ossa-López ${ }^{4,5,10}$; \\ Fredy A. Rivera-Páez ${ }^{4,11}$ \& Héctor E. Ramírez-Chaves ${ }^{4,6,12}$
}

\footnotetext{
1 Universidad de los Andes (UNIANDES), Departamento de Ciencias Biológicas, Laboratorio de Ecología de Bosques Tropicales y Primatología (LEBTYP). Bogotá, D.C., Colombia.

${ }^{2}$ Corporación Universitaria Santa Rosa de Cabal (UNISARC), Grupo de Investigación en Biología de la Conservación y Biotecnología. Santa Rosa de Cabal, Risaralda, Colombia.

${ }^{3}$ Universidad de Manizales (UMANIZALES), Facultad de Ciencias e Ingeniería, Programa de Maestría en Tecnologías de la Información Geográfica. Manizales, Caldas, Colombia.

${ }^{4}$ Universidad de Caldas (UCALDAS), Facultad de Ciencias Exactas y Naturales, Grupo de Investigación en Genética, Biodiversidad y Manejo de Ecosistemas (GEBIOME). Manizales, Caldas, Colombia.

${ }^{5}$ Universidad de Caldas (UCALDAS), Facultad de Ciencias Exactas y Naturales, Departamento de Ciencias Biológicas, Doctorado en Ciencias - Biología. Manizales, Caldas, Colombia.

6 Universidad de Caldas (UCALDAS), Centro de Museos, Museo de Historia Natural. Manizales, Caldas, Colombia.

${ }^{7}$ ORCID: http://orcid.org/0000-0003-0572-6268. E-mail: j.cepedad@uniandes.edu.co

${ }^{8}$ ORCID: http://orcid.org/0000-0001-6944-8282. E-mail: Ifrc4.20@gmail.com

9 ORCID: http://orcid.org/0000-0002-7534-994X. E-mail: alexa.cardona.giraldo@gmail.com

${ }^{10}$ ORCID: http://orcid.org/0000-0002-9079-4988. E-mail: paula.ossa@ucaldas.edu.co

${ }^{11}$ ORCID: http://orcid.org/0000-0001-8048-5818. E-mail: fredy.rivera@ucaldas.edu.co

${ }^{12}$ ORCID: http://orcid.org/0000-0002-2454-9482. E-mail: hector.ramirez@ucaldas.edu.co
}

\begin{abstract}
Bat ectoparasites have a complex natural history narrowly tied to their hosts at ecological, behavioral, and evolutionary scales. As flying and social organisms, bats represent a potential mechanism of dispersal, a source of feeding, and a roost for ectoparasite reproduction. The chiggerflea Hectopsylla pulex (Siphonaptera: Tungidae) is widely distributed across the Neotropics. Females of this ectoparasite have been found in their neosomal form on bats of the family Molossidae, Noctilionidae, Phyllostomidae, and Vespertilionidae. Here we present the record of infestation of chiggerfleas on the Argentine bat, Eptesicus furinalis (Vespertilionidae) in Colombia, representing the first record of the flea on this species, and providing novel genetic information of this poorly known flea species.
\end{abstract}

Keywords. Andes; Ectoparasite; Insectivorous bats; Peri-urban area; South America.

\section{INTRODUCTION}

The coexistence within species is mainly determined by abiotic and biotic filters that act as stabilizing agents of fitness and niche differences (HilleRisLambers et al., 2012). In the world of an ectoparasite, a host represents a habitat filter with potential resources, complex movement patterns, varied social systems, roosting behaviors, and immunologic responses (Balashov, 2006; Dick \& Ditmar, 2014). As a tradeoff, an ectoparasite requires a set of morphological, behavioral, and physiological adaptations in response to their host's traits, which drives coevolution (Balashov, 2006; Patterson et al., 2007).

Several host features could induce ectoparasite infections: first, hosts with high mobility enhance parasite colonization of new habitats (Presley \& Willig, 2008). Second, selection for a host roosting site with suitable environmental conditions for development could induce an ectoparasite interaction (Patterson et al., 2007). Third, when social hosts are spatially aggregated, parasite infections are likely to increase between individuals of the same and different sex, and between species (ter Hofstede \& Fenton, 2005; van 
Schaik et al., 2014). And, finally, stressed or immunologically suppressed hosts are more likely to be infected with ectoparasites than immunologically active or healthier hosts (Dick \& Ditmar, 2014). Conversely, to suppress the predatory pressure of an ectoparasite, the host tends to decrease its resting time and invest metabolic energy into auto- or allogrooming behaviors and immunologic responses (Balashov, 2006; ter Hofstede \& Fenton, 2005).

Bats (Chiroptera), and their related ectoparasites, are suitable models to study host-parasite interactions (Presley, 2011). The remarkable bat diversity and distribution provide a wide range of trait variation to understand the mechanisms driving patterns of parasitism (Presley, 2011; Frank et al., 2014). The chiggerflea, Hectopsylla pulex (Haller, 1880), is the only hectopsyllid parasite that occurs on bats (Hastriter \& Méndez, 2000). This species is distributed along the Neotropics from the USA (Texas) south to Argentina (Autino \& Claps, 2000, Hastriter \& Méndez, 2000). It belongs to the family Tungidae (Siphonaptera), which includes a group of fleas that have an unusual morphology, including a characteristic compression of the three thoracic segments, and a neosomic lifestyle (Hastriter \& Méndez, 2000; Whiting et al., 2008). Females, but not males, of $H$. pulex semipenetrate the hosts in regions with scarce hairs, such as the head, ears, mouth, wings, tibias, and dactylopatagia (Luz et al., 2009). Conversely, males are less host-dependent parasites, frequently found in the colony guano, searching a host only for mating (Hastriter et al., 2014). Hectopsylla pulex is associated with bats of the family Molossidae (Esberrard, 2001; Luz et al., 2009; Ramírez-Chaves et al., 2020), Noctilionidae (Méndez, 1977), Phyllostomidae (Hastriter et al., 2014), and Vespertilionidae (Hastriter \& Méndez, 2000).

Approximately 48 species of vespertilionid bats live in South America (Díaz et al., 2016), of which few species have been recorded carrying chiggerfleas (Hastriter et al., 2014). The family Vespertilionidae comprises a cos- mopolitan and highly diverse lineage of bat species with relatively stable roosting habits, cohesive social organizations, and varied feeding behaviors (Lack \& Van Den Bussche, 2010). Vespertilionids feed mainly on animal items, preying on insect populations or other invertebrate or vertebrate taxa (Kasso \& Balakrishnan, 2013). A highly developed sense of echolocation allows them to hunt insects while releasing a diverse range of wide harmonic signals during flight (Jones \& Teeling, 2006). Several vespertilionids are highly tolerant of anthropogenic landscape disturbance levels, which enables them to select for a wide range of permanent or temporary roosts (Jung \& Threlfall, 2016). Roosting sites vary from natural cavities in rocks or trees to human domestic, commercial, and industrial structures (Kunz, 1982).

The lack of studies on living vespertilionid bats with temporal flea infections makes it difficult to infer host-parasite interaction patterns within the family (Marinkelle \& Grose, 1981). Hence, documenting chiggerfleas-bat interactions is important to obtain a clearer idea of the relationships between both host and parasite. Here, we report the first record of $H$. pulex infestation on a bat of the genus Eptesicus in Colombia and update to the distribution of this ectoparasite on the family Vespertilionidae in South America.

\section{MATERIAL AND METHODS}

We report an individual of the Argentine brown bat, Eptesicus furinalis D'Orbigny \& Gervais, 1847, infested with Hectopsylla pulex on a village located at $1,590 \mathrm{~m}$ in the western slopes of the Central Cordillera, Northern Andes of Colombia. The village is in a peri-urban area on the northeastern portion of the Dosquebradas municipality $\left(04^{\circ} 51^{\prime} 34.96^{\prime \prime} \mathrm{N}, 75^{\circ} 39^{\prime} 52.53^{\prime \prime} \mathrm{W}\right)$, Department of Risaralda (Fig. 1). The landscape is a mosaic of human
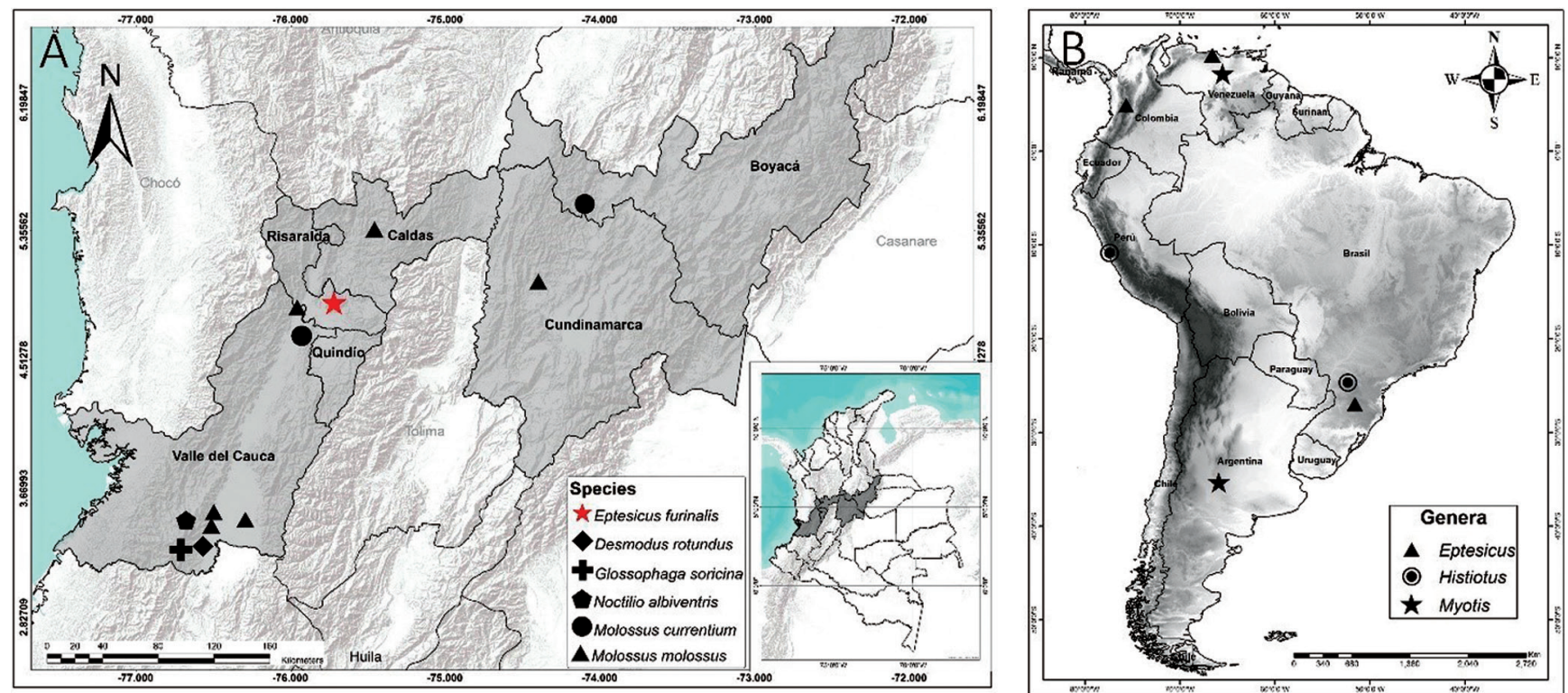

Figure 1. First document record of infestation of Hectopsylla pulex on a bat of the family Vespertilionidae in Colombia. (A) The new record in Eptesicus furinalis was obtained in Dosquebradas, Department of Risaralda (red star). Records for molossid, noctilionid, and phyllostomid species are shown. (B) Additional records of H. pulex infesting bats (Eptesicus, Histiotus, and Myotis) of the family Vespertilionidae in South America. 


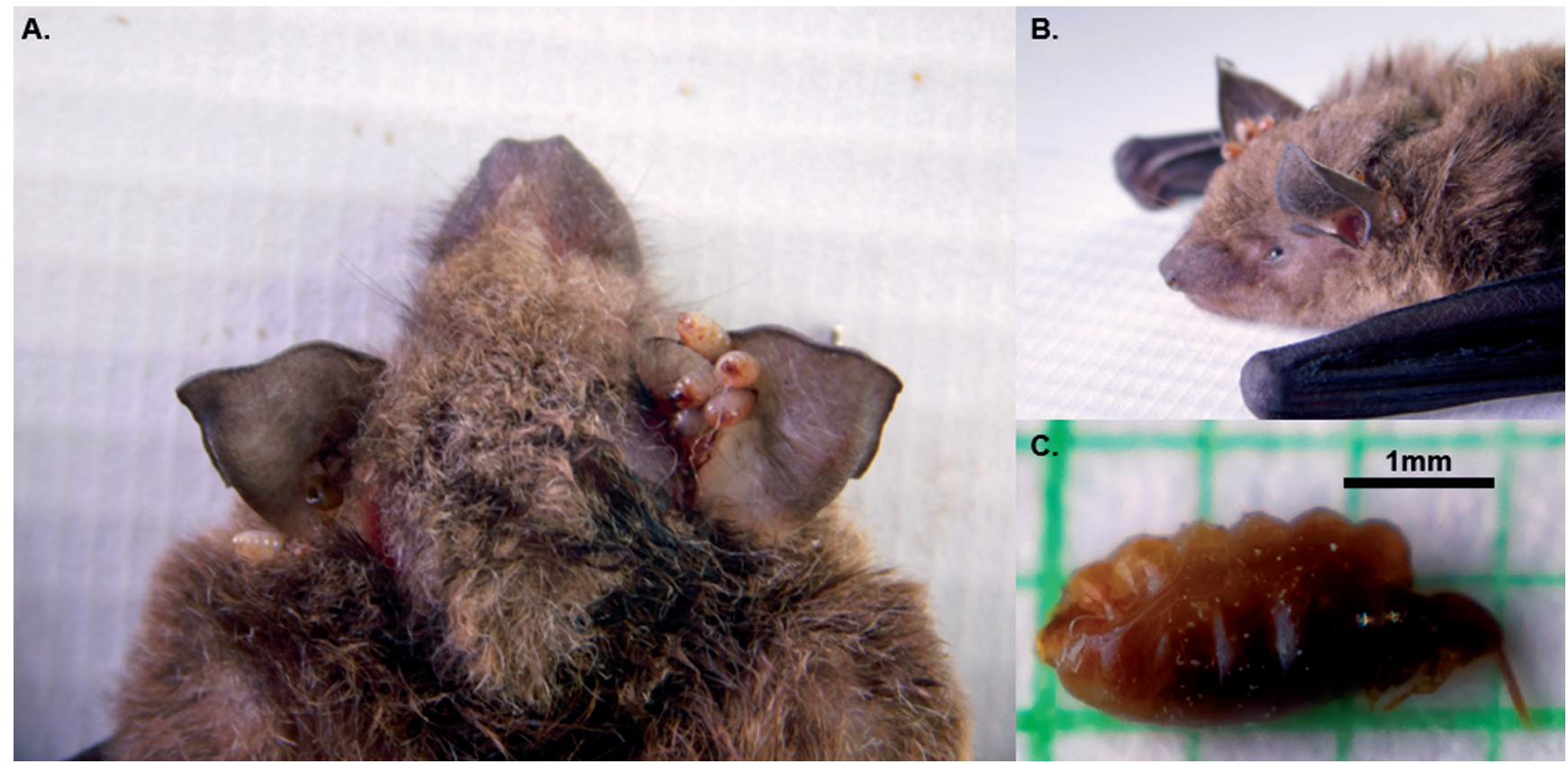

Figure 2. Adult female of the Argentine Bat, Eptesicus furinalis infested by seven individuals of Hectopsylla pulex in dorsal (A) and lateral (B) views. (C) lateral view of female, in the neosomal form of $H$. pulex. The specimen (MHN-UCa-M 3299) was collected in a peri-urban area at the northeastern part of the Municipality of Dosquebradas, Department of Risaralda, Colombia.

infrastructure, unpaved roads, shaded and open coffee, banana, and avocado crops, secondary forest remnants, and aggregations of the bamboo Guadua aungustifolia Kunth.

On $19^{\text {th }}$ June 2020 , at $18: 20 \mathrm{~h}$, an adult, non-lactating female of $E$. furinalis was found resting while attached to the wall of a house. The bat specimen was captured by hand, sexed, and identified following taxonomic keys and discrete characters including external and cranial sizes (Gardner, 2008; Díaz et al., 2016). We identified the bat as Argentine brown bat, E. furinalis based on the combination of intermediate size (forearm length, $41.98 \mathrm{~mm})$, short dorsal hair $(5.5 \mathrm{~mm})$, condylo-incisive length $(14.92 \mathrm{~mm})$, and length of the maxillary toothrow $(5.88 \mathrm{~mm})$. We collected the specimen and deposited the skin, skull, and ectoparasites in the Museo de Historia Natural, Universidad de Caldas (MHN-UCa), under the catalog number MHN-UCa-M 3299. Hectopsylla pulex individuals were distinguished based on the narrowly pointed palpus-bearing lobe of the maxilla; a rounded anterior margin of the head; an S-shaped spermathecal with a conical projection of this orifice; short and inclusive terga and sterna 2-7, lateral portions without reaching contact each other in females; a highly expanded abdomen coupled with an autoseverence of appendages (Fig. 2).

The individuals of $H$. pulex were counted and collected from the bat specimen by examining the fur using fine point forceps and photographed with a Nikon Coolpix B500 semiautomatic camera with a millimeter scale to estimate total body length for each flea specimen. Fleas were preserved and stored in $70 \%$ alcohol, at room temperature. We externally identified the chiggerfleas as $H$. pulex individuals using the taxonomic keys of Hastriter \& Méndez (2000).
After the morphological identification, two H. pulex specimens were individually processed for molecular analyses. Genomic DNA was extracted with the Wizard $^{\circledR}$ Genomic DNA Purification kit (Promega Corporation) following the standard protocol indicated by the manufacturer. DNA quality and quantity were measured using a NanoVueTM Plus spectrophotometer. PCR amplification was performed using primers flanking two target mtDNA genes. The $12 \mathrm{~S}$ rRNA gene fragment $(\approx 340 \mathrm{pb})$ was amplified using the primer pair T1B 5'-AAACTAGGATTAGATACCCT-3' and T2A 5'-AATGAGAGCGACGGGCGATGT-3' reported by Beati \& Keirans (2001). Primers LCO1490 (F) 5'-GGTCAACAAATCATAAAGATATTGG-3' y HCO2198 (R) 5'-TAAACTTCAGGGTGACCAAAAAATCA-3' were used to amplify a fragment of the cytochrome oxidase I (COI; $\approx 700 \mathrm{pb}$ ) gene (Folmer et al., 1994). The amplifications were performed on a Techne TCPLUS thermocycler, according to the following conditions: initial denaturation at $94^{\circ} \mathrm{C}$ for $2 \mathrm{~min}$, followed by 7 cycles at $94^{\circ} \mathrm{C}$ for $30 \mathrm{~s}$, $45^{\circ} \mathrm{C}$ for $30 \mathrm{~s}$, and $72^{\circ} \mathrm{C}$ for $45 \mathrm{~s}$, followed by 28 cycles at $94^{\circ} \mathrm{C}$ for $30 \mathrm{~s}, 48^{\circ} \mathrm{C}$ for $30 \mathrm{~s}$, and $72^{\circ} \mathrm{C}$ for $45 \mathrm{~s}$, completing the reaction with a final extension cycle at $72^{\circ} \mathrm{C}$ for $7 \mathrm{~min}$, for the $12 \mathrm{~S}$ rRNA gene. Initial denaturation at $95^{\circ} \mathrm{C}$ for $5 \mathrm{~min}$, followed by 5 cycles at $94^{\circ} \mathrm{C}$ for $5 \mathrm{~min}, 46^{\circ} \mathrm{C}$ for $1 \mathrm{~min} 30 \mathrm{~s}$, and $72^{\circ} \mathrm{C}$ for $1 \mathrm{~min} 30 \mathrm{~s}$, followed by $35 \mathrm{cy}$ cles at $94^{\circ} \mathrm{C}$ for $1 \mathrm{~min}, 53^{\circ} \mathrm{C}$ for $1 \mathrm{~min}$, and $72^{\circ} \mathrm{C}$ for $1 \mathrm{~min}$, completing the reaction with a final extension cycle at $72^{\circ} \mathrm{C}$ for $5 \mathrm{~min}$, for the $\mathrm{COI}$ gene. All PCR products were visualized by horizontal electrophoresis on $1 \%$ agarose gels with $1 \mathrm{X}$ TBE pH 8.0 running buffer at $110 \mathrm{v} / 50 \mathrm{~mA}$. Gels were stained with ethidium bromide and visualized on a GelDoclt ${ }^{\circledR} 2310$ Imager (UVP). PCR products were purified using the Wizard ${ }^{\circledR}$ SV Gel and PCR CleanUp System kit $\left(\right.$ Promega $\left.^{\circledR}\right)$, estimated the amount of 
Table 1. Sequences of the mitochondrial genes used in the present study. Information on the GenBank accession number, host, and reference are included.

\begin{tabular}{|c|c|c|c|c|c|}
\hline Order/Family & Species & Accession & Gene & Host & Reference \\
\hline \multirow{13}{*}{ Siphonaptera: Tungidae } & \multirow{11}{*}{ Hectopsylla pulex } & KM891526 & 12S rRNA & Unknown & \multirow{2}{*}{ Zhu et al. (2015) } \\
\hline & & KM891012 & $\mathrm{COl}$ & Unknown & \\
\hline & & MT272335 & 12S rRNA & Molossus molossus & \multirow{3}{*}{ Ramírez-Chaves et al. (2020) } \\
\hline & & MT280760 & \multirow{2}{*}{$\mathrm{COl}$} & M. molossus & \\
\hline & & MT296816 & & M. molossus & \\
\hline & & MW085036 & 12S rRNA & M. molossus & \multirow{2}{*}{ Direct submission; this study } \\
\hline & & MW136341 & $\mathrm{COl}$ & M. molossus & \\
\hline & & MW085035 & \multirow{2}{*}{ 12S rRNA } & E. furinalis & \multirow{4}{*}{ This study } \\
\hline & & MW085037 & & E. furinalis & \\
\hline & & MW136338 & \multirow{2}{*}{$\mathrm{COl}$} & E. furinalis & \\
\hline & & MW136339 & & E. furinalis & \\
\hline & \multirow{2}{*}{ Hectopsylla cypha } & KM891459 & 12S rRNA & Unknown & \multirow{2}{*}{ Zhu et al. (2015) } \\
\hline & & KM890948 & $\mathrm{COl}$ & Unknown & \\
\hline Siphonaptera:Vermipsyllidae & Dorcadia ioffi & MF124314 & mitochondrion, complete genome & Eospalax fontanierii (Rodentia) & Xiang et al. (2017) \\
\hline
\end{tabular}

DNA through fluorometric quantification on a Quantus Fluorometer $^{\mathrm{TM}}$ (Promega ${ }^{\circledR}$ ) using the QuantiFluor ${ }^{\circledR}$ dsDNA System (Promega ${ }^{\circledR}$ ). Finally, amplicons were sequenced by standard sequencing on the $\mathrm{ABI} 3730 \mathrm{xl}$ System at Macrogen Advancing Through Genomics - South Korea. The sequences obtained were evaluated and edited in the Geneious prime 2020.2.4 (https://www.geneious. com).

With the obtained sequences for both genes, we performed independent and concatenated phylogenetic analyses together with sequences of related taxa available in GenBank database (Sayers et al., 2020; NIH genetic sequence database of the National Center for Biotechnology Information) (Table 1). The final dataset was represented by a total of 408 positions for the $12 \mathrm{~S}$ and 789 for the COI genes. The analysis involved seven nucleotide sequences for $12 \mathrm{~S}$ and eight for $\mathrm{COI}$. The sequences were aligned using ClustalW (Thompson et al., 1997), and the best substitution model for each gene was selected using MEGA X (Kumar et al., 2018). The best evolutionary models were T92 (Tamura 3-parameter; Tamura, 1992) for $12 \mathrm{~S}$ rRNA, and GTR + I for COI. Based on both the alignment (single and concatenated sets of mitochondrial genes) and substitution model, intraspecific and interspecific genetic distances were calculated. The phylogenetic tree was constructed using Maximum Likelihood (ML), 1000 bootstrap replications, using MEGA X (Nei \& Kumar, 2000). The rate variation model allowed for some sites to be evolutionarily invariable (+ I, $40.24 \%$ sites) for COI. For the concatenated analysis, we selected the best-fitting models of sequence evolution $(\mathrm{GTR}+\mathrm{I})$, using the Akaike Information Criterion (AIC) calculated with ModelFinder in PhyloSuite (Zhang et al., 2020). The Maximum Likelihood (ML) analysis was conducted with IQ-TREE (Nguyen et al., 2015), 5,000 ultrafast bootstraps (Minh et al., 2013); as well as ShimodairaHasegawa-like approximate likelihood-ratio test (SH-like aLRT) for branches with 1,000 replicates (Guindon et al., 2010), all included in PhyloSuite platform (Zhang et al., 2020). Finally, we used the graphical viewer of phylogenetic trees FigTree v.1.4.3 (Rambaut, 2007). The species Dorcadia ioffi was used as outgroup, since it was a close genus for which we found $\mathrm{COI}$ and $12 \mathrm{~S}$ sequences in GenBank.

To compile information on the distribution of bat infestations by $H$. pulex in Colombia, and additional records of infestations in vespertilionids across South America (Fig. 1), we compared our record with those in the literature (e.g., Ramírez-Chaves et al., 2020), and searched for additional records in Google Scholar, Scopus (http:// www.scopus.com) and World of Science (http://www. webofknowledge.com), without time restriction for searches, and with the following keywords: 'Hectopsylla', 'Rhynchopsyllus,' 'Vespertilionidae,' 'Fleas', 'Ectoparasite', 'South America', and 'host-parasite'.

\section{RESULTS}

The Argentine brown bat, E. furinalis was infested with seven females of $H$. pulex, five of them distributed on the dorsal surface at the base of the right ear and the remaining two on the dorsal surface at the base of the left ear (Fig. 2).

The Maximum Likelihood tree with the highest log likelihood (-844.31) was obtained for the $12 \mathrm{~S}$ gene (Fig. 3), and log likelihood (-1739.63) obtained for the COI gene (Fig. 4). The species $H$. pulex was recovered as monophyletic, composed of species that parasitized the two hosts, E. furinalis and M. molossus from Colombia (Fig. 3 and Fig. 4). The ML tree with the highest log likelihood (-2677.397) was obtained for the concatenated analyses, with proportion of invariable sites of 0.445 and base frequencies of A: 0.327 C: 0.128 G: 0.129 T: 0.417 (Fig. 5).

Based on the intraspecific genetic distance, $H$. pulex showed average distances between $0,0 \%$ for the $12 \mathrm{~S}$, 0,0\%-1,6\% for the COI fragments, and distances between $0.0 \%-1.0 \%$ for the concatenated analyses; while genetic divergence values between $H$. pulex and $H$. cypha varied between $4 \%, 16.1-17,4 \%$ and $10,9-17,4 \%$ for 12 S, COI and the two genes concatenated, respectively. The genetic divergence values between $H$. pulex and $D$. ioffi were $56-61 \%, 17.8-18.91 \%$ and $16.1-30 \%$ for 12 S, COI and the two genes concatenated, respectively. 
Regarding the $H$. pulex occurrence in Colombia, we found seven previously confirmed localities (Table 2) for its occurrence associated with six bat species and three bat families (Noctilionidae, Molossidae, and Phyllostomidae). Our record is the first documented for the family Vespertilionidae in Colombia. We also gathered five confirmed localities and records of infestation of $H$. pulex in bat species of the family Vespertilionidae in South America, in the countries of Argentina, Brazil, Peru, and Venezuela (Fig. 1).

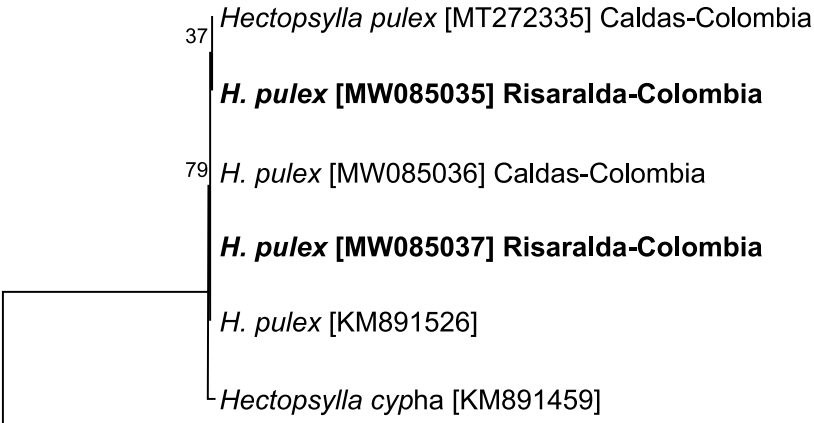

$$
\begin{aligned}
& \text { Dorcadia ioffi [MF124314] } \\
& 0.10
\end{aligned}
$$

Figure 3. Phylogenetic tree based on partial sequences of the 125 rRNA gene. The tree was inferred through Maximum Likelihood (ML) method with the Tamura 3-parameter evolution model. The sequences obtained in this study (bold) and GenBank accessions numbers are provided within brackets. Numbers at nodes are bootstrap support values.

\section{DISCUSSION}

Our record represents the first confirmed case of an Argentine bat infested with $H$. pulex, and for a member of the family Vespertilionidae in Colombia (Table 2), confirmed by both morphology and 12S rRNA, COI gene fragments and the concatenation of two genes (Fig. 3-Fig. 5). Previous records of the presence of $H$. pulex in Colombia were obtained mainly in bats of the family Molossidae (Tamsitt, 1970; Ramírez-Chaves et al., 2020), and in one species of Noctilionidae, and two of Phyllostomidae (Table 2). Similar situation occurs in the Neotropics where $H$. pulex has been recorded predominantly on bats of the families Molossidae and, to a lesser extent, in Noctilionidae, Phyllostomidae, and Vespertilionidae (Méndez, 1977; Hastriter et al., 2014). There are records of chiggerflea on vespertiliond bats from South America for only three genera: Eptesicus, Histiotus, and Myotis (Hastriter \& Méndez, 2000). In Argentina, records of $H$. pulex on Myotis sp. has been reported from Buenos Aires (Tipton \& Machado-Allison, 1972; Autino et al., 1999; Autino \& Claps, 2000). In Brazil, the chiggerflea has been reported from one specimen of Eptesicus sp. from São Paulo state (Linardi, 2011), and one of Histiotus velatus from Pará state (Tipton \& Machado-Allison, 1972; Hastriter \& Méndez, 2000). In Peru, H. pulex was recorded from Histiotus sp. found in Huaura (Macchiavello, 1948). Finally, in Venezuela, specimens of $E$. fuscus and M. nigricans from Caracas (Hastriter \& Méndez, 2000) has been reported carrying $H$. pulex females (Tipton \& MachadoAllison, 1972).

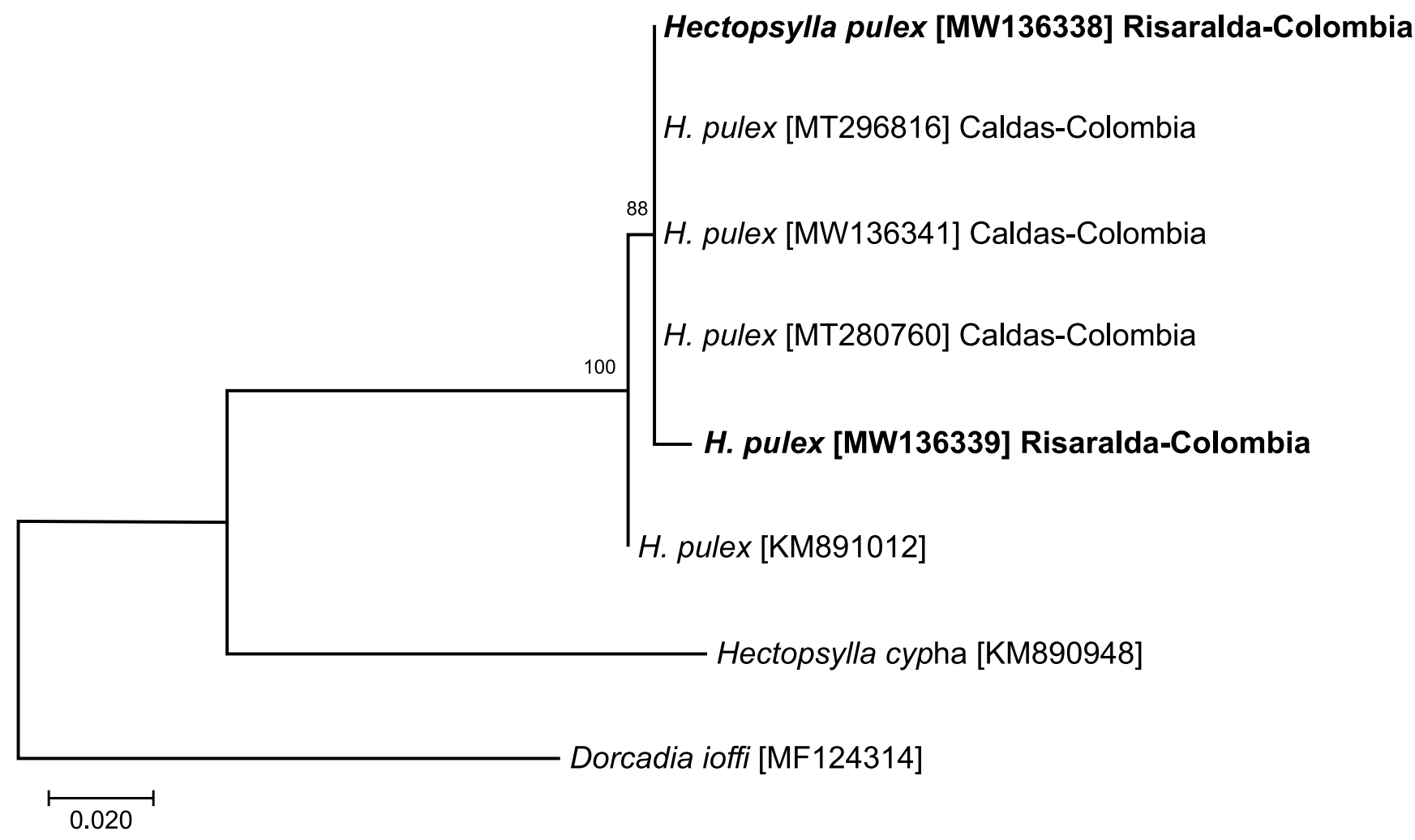

Figure 4. Phylogenetic tree based on partial sequences of the COI gene. The tree was inferred through Maximum Likelihood (ML) method with the GTR + I evolution model. The sequences obtained in this study (bold) and the GenBank accessions numbers are provided within brackets. Numbers at nodes are bootstrap support values. The tree is drawn to scale, with branch lengths measured in the number of substitutions per site. 
Table 2. Records of Hectopsylla pulex in bats (Chiroptera) in Colombia.

\begin{tabular}{|c|c|c|c|c|}
\hline Family & Taxon & Department & Elevation (m) & Reference \\
\hline Noctilionidae & Noctilio albiventris Desmarest, 1818 & Valle del Cauca & 1,100 & Méndez (1977), Hastriter \& Méndez (2000) \\
\hline \multirow[t]{2}{*}{ Phyllostomidae } & Desmodus rotundus (É. Geoffroy Saint Hilaire, 1810) & Valle del Cauca & 1,100 & Méndez (1977) \\
\hline & Glossophaga soricina (Pallas, 1766) & Valle del Cauca & 1,100 & Méndez (1977) \\
\hline \multirow[t]{3}{*}{ Molossidae } & Molossus molossus (Pallas, 1766) & Caldas, Cundinamarca, Valle del Cauca & $1,000-1,991$ & $\begin{array}{l}\text { Tamsitt (1970), Méndez (1977); Marinkelle \& Grose (1981); } \\
\text { Hastriter \& Méndez (2000); Ramírez-Chaves et al. (2020) }\end{array}$ \\
\hline & Molossus currentium Thomas, 1901 & Boyacá, Valle del Cauca & $815-1,100$ & Hastriter \& Méndez (2000) \\
\hline & $\begin{array}{l}\text { Cynomops greenhalli Goodwin, 1958, Tadarida brasiliensis } \\
\text { (I. Geoffroy, 1824), and Eumops glaucinus (Wagner, 1843) }\end{array}$ & Colombia, no specific locality & Unknown & Marinkelle \& Grose (1981) \\
\hline Vespertilionidae & Eptesicus furinalis (D’Orbigny \& Gervais, 1847) & Risaralda & 1,590 & This work \\
\hline
\end{tabular}

To our knowledge, H. pulex in South American vespertilionids are limited reported (Table 2). In contrast, vespertilionid bats are well represented in other type of ectoparasite reports for South America, where approximately $77 \%$ of species have been found infested predominantly by ectoparasites of the orders Diptera and Siphonaptera (Frank et al., 2014). Within the siphonapterans, the families Ischnopsyllidae and Tungidae have parasitic interactions with several species in the genera Myotis, Histiotus, Lasiurus, and Eptesicus (Linardi, 2011; Hastriter et al., 2014; Autino et al., 2016).

Our observation is congruent with the female-bias host selection found for other species of Siphonaptera (Presley, 2012; Ramírez-Chaves et al., 2020) but, since we have a limited sample size, we cannot make further generalizations. Furthermore, the prevalence and intensity in this host-parasite system has been only eval- uated for two species of Molossus (Molossidae) in Brazil and Colombia (Esbérard, 2001; Luz et al., 2009; RamírezChaves et al., 2020) limiting additional comparisons with other vespertilionids. Current evidence suggests that H. pulex infestations are localized on the bat ears and tragus (Esbérard, 2001; Luz et al., 2009; Hastriter et al., 2014; Ramírez-Chaves et al., 2020). These flea attachment areas could interfere with echolocation, and thus compromise the fitness of infected individuals (Hastriter et al., 2014). Previous studies on $H$. pulex suggest it is a vector of tungiasis, enhancing gram-negative bacterial infections on the host's damaged skin (Linardi \& de Avelar, 2014), and this topic is also in need of additional research.

Finally, our results have implications for the historical association of $H$. pulex with bats of different families. Previous phylogenetic analyses for Siphonaptera using genetic data (Zhu et al., 2015) did not include the host

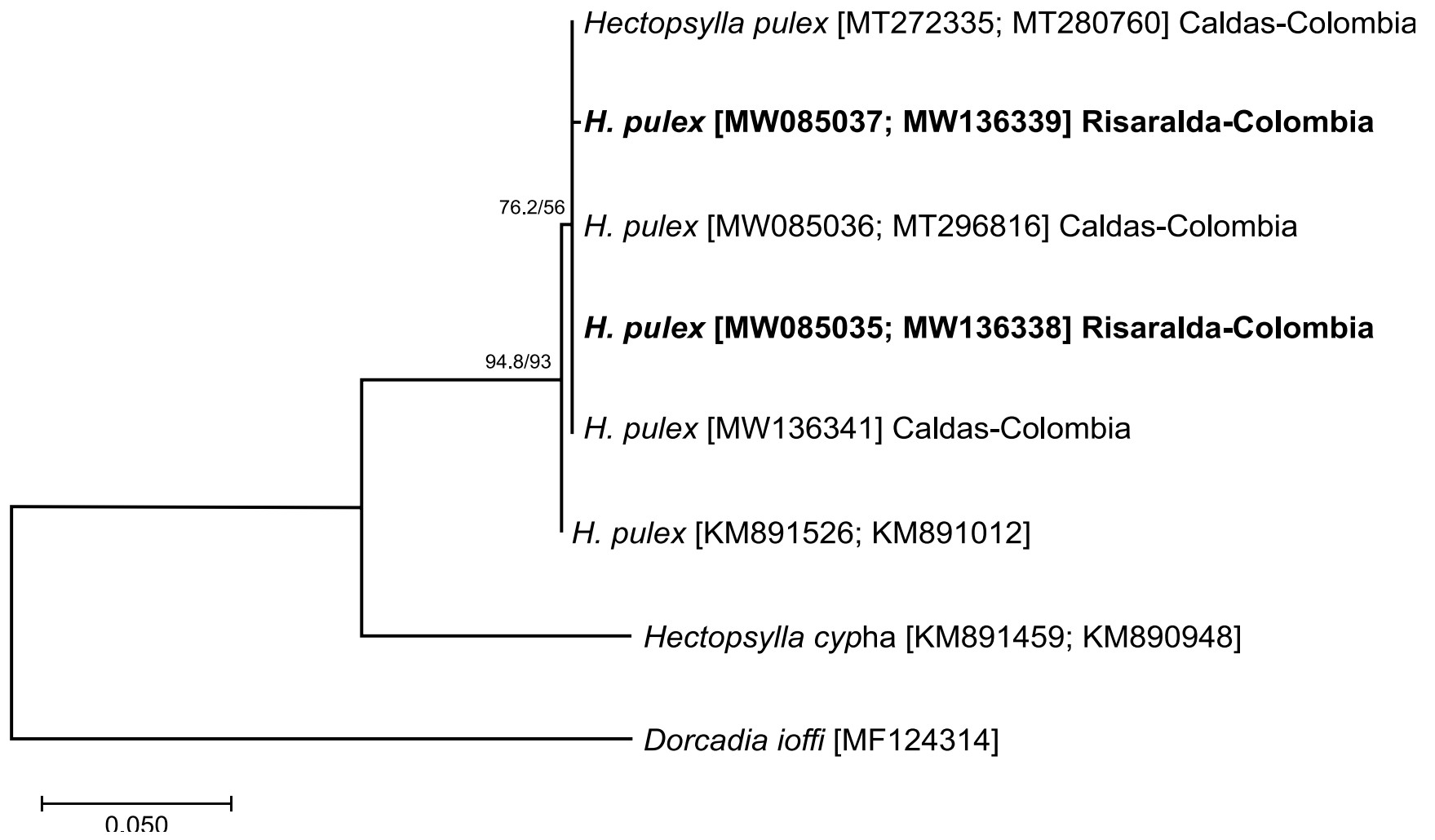

Figure 5. Phylogenetic tree inferred from the concatenation of $12 S$ and COI genes. The tree was inferred through Maximum Likelihood (ML) method with the GTR + I evolution model. The sequences obtained in this study (bold) and the GenBank accessions numbers are provided within brackets (12S; COI respectively). Numbers at nodes are above-selected branch support analysis from left to right: ultrafast bootstraps values, and Shimodaira-Hasegawa-like approximate likelihood-ratio test (SH-like aLRT). The tree is drawn to scale, with branch lengths measured in the number of substitutions per site. 
associated with the samples of $H$. pulex, limiting the comparisons of whether the same chiggerflea parasites different hosts (Ramírez-Chaves et al., 2020). Considering that Hectopsylla are strictly bat ectoparasites that do not exhibit the morphological features of other arthropod bat parasites (Whiting et al., 2018), the genetic distances observed between samples of $H$. pulex from different bat hosts are key to understand its generalist host selection behavior. However, additional H. pulex samples from different bat host are needed to draw definitive conclusions. An additional future challenge for the study of bats/H. pulex interactions is the drivers, times, and places where the interactions took place.

\section{ACKNOWLEDGMENTS}

We thank Valentina Cepeda and Daniel López from Primera Toma for their technical assistance in photography. Special thanks to Jim Patton and Julio ChacónPacheco and two anonymous reviewers for their helpful comments that improved the manuscript. We also thank the Vicerrectoría de Investigaciones y Posgrados of the Universidad de Caldas, "Convocatoria de Apoyo con Recursos Económicos a Grupos de Investigación de la Universidad de Caldas Año 2020", and for financing the seedbed project "Barreras de control peri-urbanas: el papel de los mamíferos silvestres en la circulación de hemoparásitos en la red Ecoparques de Manizales, Caldas" (2019). PAOL thanks Minciencias "Convocatoria del Fondo de Ciencia, Tecnología e Innovación del Sistema General de Regalías para la conformación de una lista de proyectos elegibles para ser viabilizados, priorizados y aprobados por el OCAD dentro del Programa de Becas de Excelencia Doctoral Bicentenario - 2019".

\section{AUTHORS' CONTRIBUTIONS}

J.C.C.D. field data collection, specimen preparation, and wrote the paper. L.F.R.C. allocated H. pulex records in vespertilionids from South America. H.E.R.C., A.C.G., P.A.O.L., F.A.R.P. prepared maps, obtained genetic data, confirmed the bat and flea identification, analyzed the data, and wrote the paper.

\section{REFERENCES}

Autino, A.G. \& Claps, G.L. 2000. Catalogue of the ectoparasitic insects of the bats of Argentina. Insecta Mundi, 14: 193-209.

Autino, A.G.; Claps, G.L. \& Barquez, R.M. 1999. Insectos ectoparásitos de murciélagos de Las Yungas de la Argentina. Acta Zoologica Mexicana (nueva serie), 78: 119-169.

Autino, A.G.; Ortiz, F.; Claps, G.L. \& Bracamonte, J.C. 2016. New host and locality records for chiropteran ectoparasites from Jujuy and Salta provinces, Argentina. Check List, 12(3): 1895.

Balashov, Y.S. 2006. Types of parasitism of acarines and insects on terrestrial vertebrates. Entomologicheskoe Obozrenie, 85(4): 918-936.
Beati, L. \& Keirans J.E. 2001. Analysis of the systematic relationships among ticks of the genera Rhipicephalus and Boophilus (Acari: Ixodidae) based on mitochondrial 125 ribosomal DNA gene sequences and morphological characters. Journal of Parasitology, 87: 32-48

Díaz, M.M.; Solari, S.; Aguirre, L.F.; Aguiar, L. \& Barquez, R.M. 2016. Clave de Identificación de los murciélagos de Sudamérica-Chave de identificação dos morcegos da America do Sul. Buenos Aires, Editorial Magna. 160p. (Publicación Especial № 2. Programa de Conservación de los Murciélagos de Argentina)

Dick, C.W. \& Dittmar, K. 2014. Parasitic bat flies (Diptera: Streblidae and Nycteribiidae): host specificity and potential as vectors. In: Klimpel, S. \& Mehlhorn, H. (Eds.). Bats (Chiroptera) as vectors of diseases and parasites. Berlin, Springer. p. 131-155.

Esbérard, C. 2001. Infestation of Rhynchopsyllus pulex (Siphonaptera: Tungidae) on Molossus molossus (Chiroptera) in Southestern Brazil. Memórias do Instituto Oswaldo (ruz, 96(8): 1169-1170.

Folmer, 0.; Black, M.; Hoeh, W.; Lutz, R. \& Vrijenhoek, R. 1994. DNA primers for amplification of mitochondrial cytochrome $c$ oxidase subunit I from diverse metazoan invertebrates. Molecular Marine Biology and Biotechnology, 3: 294-299

Frank, R.; Münster, J.: Schulze, J.; Liston, A. \& Klimpel, S. 2014. Macroparasites of Microchiroptera: bat ectoparasites of Central and South America. In: Klimpel, S. \& Mehlhorn, H. (Eds.). Bats (Chiroptera) as vectors of diseases and parasites. Berlin, Springer. p. 87-130.

Gardner, A.L. (Ed.). 2008. Mammals of South America, volume 1: marsupials, xenarthrans, shrews, and bats (Vol. 2). University of Chicago Press.

Guindon, S.; Dufayard, J.F.; Lefort, V.; Anisimova, M.; Hordijk, W. \& Gascuel, 0.2010 . New algorithms and methods to estimate maximum-likelihood phylogenies: assessing the performance of PhyML 3.0. Systematic Biology, 59(3): 307-321.

Hastriter, M.W. \& Méndez E. 2000. A review of the flea genera Hectopsylla Frauenfeld and Rhynchopsyllus Haller (Siphonaptera: Pulicidae). Proceedings of the Entomological Society of Washington, 102(3): 612-624.

Hastriter, M.W.; Meyer, M.D.; Sherwin, R.E. \& Dittmar, K. 2014. New distribution and host records for Hectopsylla pulex Haller (Siphonaptera, Tungidae) with notes on biology and morphology. ZooKeys, 389: 1-7.

HilleRisLambers, J.; Adler, P.B.; Harpole, W.S.; Levine, J.M. \& Mayfield, M.M. 2012. Rethinking community assembly through the lens of coexistence theory. Annual review of Ecology, Evolution, and Systematics, 43: 227-248.

ter Hofstede, H.M. \& Fenton, M.B. 2005. Relationships between roost preferences, ectoparasite density, and grooming behaviour of Neotropical bats. Journal of Zoology, 266(4): 333-340.

Jones, G. \& Teeling, E.C. 2006. The evolution of echolocation in bats. Trends in Ecology \& Evolution, 21(3): 149-156.

Jung, K. \& Threlfall, C.G. 2016. Urbanisation and its effects on bats - a global meta-analysis. In:Voigt, C. \& Kingston, T. (Eds.). Bats in the Anthropocene: conservation of bats in a changing World. Cham, Springe. p. 13-33.

Kasso, M. \& Balakrishnan, M. 2013. Ecological and economic importance of bats (Order Chiroptera). International Scholarly Research Notices, 2013: 187415.

Kumar, S.; Stecher, G.; Li, M.; Knyaz, C. \& Tamura, K. 2018. Mega X: molecular evolutionary genetics analysis across computing plataforms. Molecular Biology and Evolution, 35: 1547-1549.

Kunz, T.H. 1982. Roosting ecology of bats. In: Kunz, T.H. (Ed.). Ecology of Bats. New York, Plenum Press. p. 1-55.

Lack, J.B. \& Van Den Bussche, R.A. 2010. Identifying the confounding factors in resolving phylogenetic relationships in Vespertilionidae. Journal of Mammalogy, 91(6): 1435-1448.

Linardi, P.M. 2011. Checklist de Siphonaptera (Insecta) do Estado de São Paulo. Biota Neotropica, 11: 607-617. 
Linardi, P.M. \& de Avelar, D.M. 2014. Neosomes of tungid fleas on wild and domestic animals. Parasitology Research, 113(10): 3517-3533.

Luz, J.L.; Costa, L.D.M.; Gomes, L.A.C. \& Esbérard, C.E.L. 2009. The chiggerflea Hectopsylla pulex (Siphonaptera: Tungidae) as an ectoparasite of freetailed bats (Chiroptera: Molossidae). Memórias do Instituto Oswaldo Cruz, 104(4): 567-569.

Macchiavello, A. 1948. Siphonaptera de la Costa Sur-Occidental de América:(Primera lista y distribución Zoo-Geográfica). Boletín de la Oficina Sanitaria Panamericana (OSP), 27: 412-460.

Marinkelle, C. \& Grose, E.S. 1981. A list of ectoparasites of Colombian bats. Revista de Biología Tropical, 29(1): 11-20.

Méndez, E. 1977. Mammalian-Siphonapteran associations, the environment, and biogeography of mammals of southwestern Colombia. Quaestiones Entomologicae, 13(3): 92-182.

Minh, B.Q.; Nguyen, M.A. \& von Haeseler, A. 2013. Ultrafast approximation for phylogenetic bootstrap. Molecular Biology and Evolution, 30(5): 1188-1195.

National Center for Biotechnology Information (NCBI) [Internet]. Bethesda (MD): National Library of Medicine (US), National Center for Biotechnology Information; [1988] - [cited 2020 Dec 10]. Available: https://www.ncbi. nlm.nih.gov.

Nei, M. \& Kumar, S. 2000. Molecular Evolution and Phylogenetics. New York, Oxford University Press.

Nguyen, L.T.; Schmidt, H.A.; von Haeseler, A. \& Minh, B.Q. 2015. IQ-TREE: a fast and effective stochastic algorithm for estimating maximum-likelihood phylogenies. Molecular Biology and Evolution, 32: 268-274.

Patterson, B.D.; Dick, C.W. \& Dittmar, K. 2007. Roosting habits of bats affect their parasitism by bat flies (Diptera: Streblidae). Journal of Tropical Ecology, 23: 177-189.

Presley, S.J. 2011. Interspecific aggregation of ectoparasites on bats: importance of hosts as habitats supersedes interspecific interactions. Oikos, 120(6): 832-841.

Presley, S.J. 2012. Sex-based population structure of ectoparasites from Neotropical bats. Biological Journal of the Linnean Society, 107: 56-66.

Presley, S.J. \& Willig, M.R. 2008. Intraspecific patterns of ectoparasite abundances on Paraguayan bats: effects of host sex and body size. Journal of Tropical Ecology, 24: 75-83.

Rambaut, A. 2007. FigTree v1.4.3, A Graphical Viewer of Phylogenetic Trees. Available: http://tree.bio.ed.ac.uk/software/figtree.
Ramírez-Chaves, H.E.; Tamayo-Zuluaga, A.F.; Henao-Osorio, J.J.; CardonaGiraldo, A.; Ossa-López, P.A. \& Rivera-Páez, F.A. 2020. The chiggerflea Hectopsylla pulex (Siphonaptera: Tungidae): Infestation on Molossus molossus (Chiroptera: Molossidae) in the Central Andes of Colombia. Zoologia, Curitiba, 37: e53092.

Sayers, E.W.; Cavanaugh, M.; Clark, K.; Ostell, J.; Pruitt, K.D. \& Karsch-Mizrachi, I. 2020. GenBank. Nucleic Acids Research, 48(D1): D84-D86.

Tamsitt, J.R. 1970. Records of bat ectoparasites from the Caribbean region (Siphonaptera, Acarina, Diptera). Canadian Journal of Zoology, 48(5): 1093-1097.

Tamura, K. 1992. Estimation of the number of nucleotide substitutions when there are strong transition-transversion and $\mathrm{G}+\mathrm{C}$-content biases. Molecular Biology and Evolution, 9(4): 678-687.

Thompson, J.D.; Gibson, T.J; Plewniak, F.; Jeanmougin, F. \& Higgins, D.G. 1997. The CLUSTAL $X$ windows interface: flexible strategies for multiple sequence alignment aided by quality analysis tools. Nucleic Acids Research, 25(4): 4876-4882.

Tipton, V.J. \& Machado-Allison, C.E. 1972. Fleas of Venezuela. Brigham Young University Science Bulletin, 17: 1-11

van Schaik, J.; Kerth, G.; Bruyndonckx, N. \& Christe, P. 2014. The effect of host social system on parasite population genetic structure: comparative population genetics of two ectoparasitic mites and their bat hosts. BMC Evolutionary Biology, 14(1): 18.

Whiting, M.F.; Whiting, A.S.; Hastriter, M.W. \& Dittmar, K. 2008. A molecular phylogeny of fleas (Insecta: Siphonaptera): origins and host associations. Cladistics, 24(5): 677-707.

Xiang, H.T.; Wen, F.Q. \& Wang, G.L. 2017. The complete nucleotide sequence of the mitochondrial genome of Dorcadia ioffi (Siphonaptera: Vermipsyllidae). Mitochondrial DNA Part B, 2: 389-390.

Zhang, D.; Gao, F.; Jakovlić, I.; Zou, H.; Zhang, J.; Li, W.X. \& Wang, G.T. 2020. PhyloSuite: An integrated and scalable desktop platform for streamlined molecular sequence data management and evolutionary phylogenetics studies. Molecular Ecology Resources, 20(1): 348-355.

Zhu, Q.; Hastriter, M.W.; Whiting M.F. \& Dittmar, K. 2015. Fleas (Siphonaptera) are Cretaceous and evolved with Theria. Molecular Phylogenetics and Evolution, 90: 129-139. 